\title{
Forms of Recall - Politics of Memory. Memory as the Non-Chronological Narrative Form of Historical-Political Identity Quest in the Kádár Regime and Its Survival in the Postcommunist Period
}

\author{
Gábor GELENCSÉR \\ Eötvös Loránd University (Budapest, Hungary) \\ Department of Film Studies \\ gelencser.gabor@btk.elte.hu
}

\begin{abstract}
In the film art of the Kádár regime the modernist non-chronological narrative mode became the dominant form of remembrance and communicative memory. In the 35-year period between 1956 and 1990 we can find thirty-five films of this type (e.g. Dialogue [Párbeszéd, János Herskó, 1963], Twenty Hours [Húsz óra, Zoltán Fábri, 1965], Cold Days [Hideg napok, András Kovács, 1966], Love [Szerelem, Károly Makk, 1971], Lovefilm [Szerelmesfilm, István Szabó, 1970], Diary for My Children [Napló gyermekeimnek, Márta Mészáros, 1982]), the majority of which thematize the communicative memory of the recent past of the period (World War II, the Hungarian Holocaust, the 1950s, 1956, the Kádár consolidation) as opposed to the amnesia politics of the time. Although this cinematic corpus is connected to the film history of the Kádár era with all its elements (form: modernism; theme: communicative memory; political discourse: recollection; official politics of memory; the counterdiscourse of Kádár's amnesia politics), it survives in the postcommunist period (e.g. Hungarian Fragment [Pannon töredék, András Sólyom, 1998], White Palms [Fehér tenyér, Szabolcs Hajdu, 2006], Mom and Other Loonies in the Family [Anyám és más futóbolondok a családból, Ibolya Fekete, 2015]). After presenting the non-chronological narrative form of historical-political identity quest, the paper seeks to find reasons for the survival of this form and tries to draw conclusions regarding the social aspect and modes of expression of the Hungarian film history of the postcommunist period. ${ }^{1}$
\end{abstract}

Keywords: Hungarian film history, non-chronological narrative form, Kádár regime, postcommunist period.

1 This work was created within the framework of the research project The Social History of Hungarian Film, supported by the National Research, Development and Innovation Office, project number 116708. 
1.

In my paper I seek connections between one of the narrative procedures present in the film art of the Kádár era and the issue of social identity, then I make references to the survival of this connection in contemporary Hungarian film.

After the period of socialist realism, from 1954 on, the rebirth of Hungarian film took place in a formal and conceptual sense; after a long period of transition, by 1963, it reached the standards of European modernism. The film directors of the Hungarian New Wave of the 1960s took over a set of formal procedures from European modernist auteurs. From among the three major principles of modern art, namely subjectivity, abstraction and reflexivity (Kovács 2005, 87), the path of reflection is followed by only a few; abstraction is linked to the name of one single auteur, Miklós Jancsó, who does not simply take over but creates this modernist form; while subjectivity is widely present in the oeuvre of Hungarian film directors.

Two form procedures of subjectivity have evolved in modernist film. One is related to time, the other one is in connection with image/sound; the former affects narration, the latter concerns the audiovisual sphere. The subjectivization of time can be carried out by dissolving the chronology of narration. The narrative steps of this conventional solution, which can be linked to the classical Hollywood type narration already spread at the dawn of modernism, are as follows: 1 . The suspension of the objective narratorial position and its assignment to the subjective viewpoint of a particular character; 2 . the interruption of the continuity of narration; 3. return to the continuous present after the narrated past (flashback) or future (flashforward) event; 4. concomitantly, return from the subjective angle to the objective narrative viewpoint. Thus, in the Hollywood type narration the dissolution of chronology can be assigned a role only by emphasizing the continuity of narration. In the modern film, the principle of continuity undergoes a change: it is transferred from the objective structuring principle to the subjective one, that is, the objective criterion of continuity is overwritten by the criterion of subjectivity. Modernism extends the insular subjectivity of the classical mode of narration, clearly delimited from the objective point of view and the present time of narration, to the entire narration. The characteristic stages of this form principle are as follows: 1 . insertion of several flashback and/or flashforward sequences into narration; 2. insertion of several remembering subjects into narration; 3. lack of signification/lack of certainty concerning the present/past, present/future changes; 4 . lack of signification/lack of certainty concerning the recalling subjects. The endpoint of the process is the narration dissolving the continuity of narration, fully subjectivizing chronology and point of view, such as Alain Resnais's much quoted classic, Last Year at Marienbad (L'année dernière à Marienbad, 1961). As concerns style, the large and diverse spectrum in between the classical-objective and modernist-subjective forms is the most 
exciting. The majority of the Hungarian films examined in my paper are situated in this intermediary domain.

In the audiovisual sphere subjectivity refers to the referentiality of the image and sound universe. Accordingly, similarly to the dissolution of chronology, within the classical Hollywood type narration we can distinguish realistic images and/or sounds corresponding to the diegesis and mental images and/or sounds corresponding to the character's subjectivity. The blurring of the boundary and status of subjective images/sounds takes place similarly to, and through, the dissolution of chronology, and the endpoint is, again, the narrative that can be interpreted clearly as mental image/sound.

As concerns form, time/chronology and the subjectivity of the world of images/ sounds can be closely related; one may result from the other and vice versa (as in the case of the aforementioned Last Year at Marienbad), besides, there can be found solutions creating the two kinds of subjectivity with the same form device. Such is, for instance, the associative quick montage imitating the unlimited flow of consciousness, frequently used in Hungarian film.

Modern Hungarian film creates subjectivity mainly through the dissolution of chronology; the same form principle manifests in the shaping of visual/auditive subjectivity. Within the Kádár era, that is, in the premodern (1957-1962) and modern (1963-1969) periods of Hungarian film history, then in the seventies (1970-1979) and eighties (1980-1989), less pronounced in terms of form, thirty-five non-chronological films can be found: 1. György Révész: At Midnight (Éjfélkor, 1957); 2. Imre Fehér: Truth Cannot Be Hidden (Húsz évre egymástól, 1962); 3. János Herskó: Dialogue (Párbeszéd, 1963); 4. Zoltán Fábri: Darkness in Daytime (Nappali sötétség, 1963); 5. Márton Keleti: Evidence (Ha egyszer húsz év múlva, 1964); 6. Frigyes Mamcserov: The Doctor's Death (Az orvos halála, 1965); 7. Márk Novák: The Martyrdom of St. John (Szentjános fejevétele, 1965); 8. Zoltán Fábri: Twenty Hours (Húsz óra, 1965); 9. András Kovács: Cold Days (Hideg napok, 1966); 10. István Szabó: Father (Apa, 1966); 11. Zoltán Fábri: Late Season (Utószezon, 1966); 12. Pál Zolnay: The Sack (...hogy szaladnak a fák!, 1966); 13. István Gaál: Baptism (Kereszteló, 1967); 14. Pál Zolnay: You Were a Prophet, My Dear (Próféta voltál szívem, 1968); 15. Viktor Gertler: The Last Circle (Az utolsó kör, 1968); 16. Zoltán Várkonyi: Face to Face (Szemtól szembe, 1970); 17. Károly Makk: Love (Szerelem, 1970); 18. István Szabó: Love Film (Szerelmesfilm, 1970); 19. György Révész: A Journey Around My Skull (Utazás a koponyám körül, 1970); 20. Zoltán Huszárik: Sindbad (Szindbád, 1971); 21. György Révész: There Was Once a Family (Volt egyszer egy család, 1972); 22. István Szabó: 25, Fireman’s Street (Tüzoltó utca 25., 1973); 23. Károly Makk: Cats Play (Macskajáték, 1974); 24. Zoltán Fábri: The Unfinished Sentence (141 perc a Befejezetlen mondatból, 1974); 25. János Rózsa: Dreaming Youth (Álmodó ifjúság, 1974); 26. Ferenc Grunwalsky: Requiem for a Revolutionary (Vörös rekviem, 1975); 27. Imre 
Gyöngyössy: Expectations (Várakozók, 1975); 28. Zoltán Fábri: The Fifth Seal (Az ötödik pecsét, 1976); 29. Rezső Szörény: Reflections (Tükörképek, 1976); 30. György Révész: Who Has Ever Seen Me? (Ki látott engem?, 1977); 31. Pál Zolnay: Shaman (Sámán, 1977); 32. Péter Szász: The Great Love of Your Life and How to Forget It (Hogyan felejtsük el életünk legnagyobb szerelmét?, 1979); 33. József Magyar: Thorny Past (Korkedvezmény, 1979); 34. Zoltán Fábri: Requiem (Requiem, 1981); 35. Márta Mészáros: Diary for My Children (Napló gyermekeimnek, 1982). Before examining the films thematically, it is worth surveying the film-historical significance of this form principle from various perspectives.

\section{2.}

First let us consider the creators of the thirty-five films. The thirty-five films are signed by twenty-two film directors; only five of them made more than one nonchronological film: Károly Makk made two, István Szabó and Pál Zolnay made three each, György Révész made four and Zoltán Fábri made six. It follows from this that the non-chronological form is not appropriated by one auteur or another, and although this procedure is closer to some film directors than others, a wide range of film directors are involved in it. Secondly, the generational division of the film directors is significant. Most of these films were made by the generation starting their career in the fifties; those starting their career in the sixties made fewer and fewer. The downward trend is not dramatic; besides, the more profound involvement of those starting their career in the fifties is also explained by the fact that this is the period when the non-chronological form is spread in European film art. Finally, if we consider the temporal distribution of the films, we also meet approximate uniformity, except for the beginning and end of the period, which requires explanation. At the beginning of the period, in 1957, there is one single film which, albeit corresponding to the non-chronological form, is still closer to the classical conventions, and as such, occupies a typically connective position. Following this, after a few years' interruption, it is only the New Wave that starts to apply the dissolution of chronology, with a special intensity at the zenith of the sixties and at the age boundary of the sixties and seventies. By the eighties this modernist form withers away; similar films born at the end of the decade and in the following period already belong to the era following the regime change, thus they testify to the survival of this form in changed political and poetical circumstances.

Thus, the non-chronological form can be regarded as a representative modernist procedure in the film art of the Kádár era. The ensuing question is what this form actually represents: as concerns Hungarian film, to what extent does the nonchronological form develop in a particular way under the influence of European modernism? 


\section{3.}

As we could see, the non-chronological form expresses the basic principle of modern film related to subjectivity. Contrary to this, Hungarian film associates subjectivity, and in connection with it, recall and memories themselves, created through the non-chronological form, with community rather than with the individual subject. In the vast majority of the non-chronological Hungarian films the subject matter of recall is aimed at collective rather than subjective memory. All this is proven by the thematic survey of the films belonging to this group. Accordingly, from among the thirty-five films, recall is directed at the private past only in eight cases; in the rest of the films the subject of recall is twentieth-century Hungarian history. Also in the case of the eight films, the social motivation can be excluded only from one single film, Zoltán Huszárik's Sindbad: the film examines the abstract meaning of time in the sensory, corporeal medium of subjectivity. The treatment of chronology of the other seven films is related to the present time, that is, to a few weeks, days or hours past, rather than to historical time; besides, the motivation of the storyline is profoundly shaped by direct social, political or ideological factors.

In the case of the other twenty-seven films it is worth further specifying the evoked historical periods. Accordingly, the majority of non-chronological films process the period spanning from World War II to the contemporary present. This is followed, in equal distribution, by films evoking the fifties and 1956, as well as World War II, the 1919 Hungarian Soviet Republic, and the thirties.

What conclusions can be drawn from this? Firstly, that in Hungarian film the modernist non-chronological form aimed at expressing subjectivity represents collective rather than subjective memory (Murai 2008, 19). This confirms the social orientation of the film art in the Kádár era, according to which even such a basically subjective form as non-chronological narration can be interpreted mostly in correlation with the social purport. The thematic distribution of collective memories evoked by the films draws attention to the fact that they are predominantly directed at live, personally experienced communicative memory going back to forty-fifty years (Assmann 1992, 20; Murai 2008, 38), and a smaller part of them evokes cultural memory looking back at a more distant past (Assmann 1992, 21). However, the proximity of the particular eras and especially the thematization of the process of recall itself lead to the overlapping of the two kinds of memory.

In close connection with the above remark, a further question can be raised. If we talk about the subjective form of recall, but it is directed at collective memory, what can be the motivation of the story with such a form and subject matter? Motivation as the result of subjective recall and collective memory can be identified in the creation of social identity. In the evoked historical periods 
the aim of communicative memory is current political, whereas the purpose of cultural memory is to create a longer-term historical identity. Nevertheless, similarly to communicative and collective memory, the two kinds of identity, the proximity of the evoked periods and the thematization of the process of recall may overlap. More specifically, historical identity may turn into political identity, which also expresses the close connection and interdependent character of the two. Finally, in connection with this form, it is worth drawing attention to those further circumstances which can only be revealed through the ever closer reading of the particular films.

\section{4.}

The Kádár era as Soviet type one-party dictatorship, dominates the discourse of power with administrative tools (Foucault 1971). At the same time, the swiftly consolidating Kádár regime does this with sophisticated means, in which culture, especially film in the sixties, fulfils an important role. A determining feature of the discourse of power in the Kádár era is the politics of memory and amnesia (György 2010). Which historical event can be recalled and which cannot? How should particular historical events be recalled? The aim of all this is to create the historical and political identity complying with the discourse of power. The question is to what extent the collective memory of non-chronological films complies with the discourse of power of the Kádár era and to what extent it can be regarded as the counter-discourse of the regime.

In connection with the concept of memory, the political development linked to the consolidation of the Kádár regime, emerging in parallel with the New Wave of the sixties, has to be highlighted. The condition of consolidation is the compromise with society and the leading intellectuals. The compromise with society is carried out mainly on an economic level; with the intellectuals it is effected on an ideological one. The economic conciliation led to the new economic mechanism of the sixties; the ideological one resulted in a more liberal cultural policy hallmarked by György Aczél's name. The false and propagandistic discourse of power of the fifties and following 1956 has no longer place in this cultural policy, while the freedom of political expression has no place either. The consolidating Kádár regime - in which thus one no longer has to lie but cannot yet tell the truth - tries to dissolve the controversial relationship with the past by the social imperative of amnesia. If it is not possible to remember as it complies with our discourse, but we cannot permit remembering as it is desired by the society, especially by the leading intellectual elite and the artist intellectuals with a traditionally prestigious role, among them the film directors just getting into the focus of attention, then, we would rather not remember, the power says. 
It is 1956 (also due to Kádár's personal involvement), the ensuing retaliations, the Imre Nagy trial, the fifties and, strangely, the Holocaust, that get into the centre of the amnesia politics of the consolidating Kádár regime. The non-chronological films, however, through their determining form principle, thematize the process of remembering itself, and thus, irrespective of their subject matter, concept of history and ideology, they can be interpreted as the counter-discourse of the Kádárian amnesia politics. In this respect the non-chronological form will play an especially significant role, while it subjectivizes the image created about the past, withdrawing it through this gesture from under the authority of the discourse of power; besides, this form thematizes memory itself, contrary to the amnesia politics of the era.

If we examine again the range of themes of non-chronological films based on the evoked historical periods, we obtain additional data confirming the argument that these films actually form the position against the Kádárian discourse of power. The majority of films are centred on the period of communicative memory spanning from World War II to the contemporary present; the period of the fifties also forms part of the thus constituted historical-social continuity as the predecessor of the current regime. The Kádár era, however, tried to dissociate itself from the Rákosi years; it is not accidental that the films about the fifties could proliferate when the era could be represented as a completed event, as a "costume film" (Kovács 2002, 287). In the non-chronological form, the thematization of memory contradicts this very discourse of power.

We meet a similar counter-discourse in the films evoking the Holocaust, which constitute the second largest group regarding the subject matter. In half of the films the voice of conscience is rendered, which the subjectivity of the non-chronological form is especially suitable for, and which also alludes to an unresolved conflict at the level of society, deemed to oblivion by the discourse of power.

\section{5.}

If we analyse the ideological purport of non-chronological films closely, film by film, then we will surely get a nuanced image; still, it will not alter significantly, it will rather be confirmed. The memories themselves, the interpretation of the historical past could even support the Kádárian consolidation, as in Twenty Hours, the best-known and most debated film in this respect. (Besides the Social and Professional Main Prize as well as the Film Critics' Grand Prize of the 1965 Hungarian Feature Film Week, it wins the Grand Prize and the FIPRESCI Prize of the Moscow International Film Festival.) Nonetheless, such a judgement of Twenty Hours must also be complex like the film itself: it represents the political 
events between 1945 and 1965 from several perspectives (the non-chronological form provides an ideologically progressive view), it juxtaposes several political opinions, finally, no doubt, it highlights the truth of the character embodying the ideology of the Kádárian consolidation from among several private truths, as the result of lessons learnt from the past, setting it as an example to follow for the present, for the spectator.

Fábri's commitment to the non-chronological mode of narration is marked by the fact that Twenty Hours is the central piece of a "trilogy" in the sense of form: it constitutes a transition from the traditional flashback structure of Darkness in Daytime to the image and montage solutions of Late Season representing the time shifts and slips in a non-conventional way. In the case of Twenty Hours, the dissolution of chronology is most closely connected to the ideological purport: this is why the film (together with András Kovács's Cold Days) becomes the characteristic piece of the modernism of the 1960s.

The non-chronological form is supplemented with an element present in both Twenty Hours and Cold Days, namely the multiplication of the narrative point of view. Thus the narrative structure presenting the multiple time planes from several viewpoints violates the cinematic convention in two respects, in terms of both linearity and focalization. By the sixties each solution in turn had already had a considerable universal film historical tradition and we can come across a few exceptional examples of their joint application in classical (Orson Welles: Citizen Kane, 1941) and in modern film (Kurosawa Akira: Rashomon, 1950); in modernism this becomes the standard procedure (and in the age of the postmodern film it almost becomes conventional). In any case, in Hungarian film history the joint dissolution and juxtaposition of time planes and characters' consciousnesses/viewpoints is a new phenomenon, what is more, it has literary models: Twenty Hours is the adaptation of Ferenc Sánta's novel, and Cold Days is the adaptation of Tibor Cseres's novel, both written in those times. While relying on the narrative mode of the literary works, the two films also develop further the literary procedures. Arising from the specificities of the medium (montage; the realism of the filmic image), the alternation and superimposition of time planes and viewpoints even increases the fundamental poetical and political aim of the literary works, namely the suggestion of the complexity and relativity of historical truth, as opposed to the reductive and false image of history of the previous period. At the same time, it is worth highlighting that the writers - as emphasized by both of their contemporary monographers (Vasy 1975, 142; Zappe $1975,91)$ - also draw on film art when elaborating their literary procedures.

Although in the film versions the narrative representation of this concept cannot be fully identified with the tendency towards abstraction characteristic of modernism, Fábri's and Kovács's films challenge the ideological boundaries of the Kádárian consolidation. Contrary to the dissolution of chronology and 
multiplication of viewpoints characteristic of modernist film, which formulates the scepticism towards the possibility of knowing the world, evidently, the adaptations of Twenty Hours and Cold Days do not reach as far as such abstract epistemological/philosophical questions (this will take place in two further pairs of literary works and their adaptations, both being paradigm changing works also from the viewpoint of dissolution of chronology: in Károly Makk's Love and especially in Zoltán Huszárik's Sindbad; what is more, in the former one not irrespective of the political purport either). Fábri's and Kovács's modernist form is destined to strengthen the spirit of the reformist politics of the sixties through the cathartic formulation of historical and political identity. However, beyond this, Twenty Hours also allows a reading conforming to the Kádárian consolidation politics, thus from the perspective of the politics of memory this film is more representative (although poetically Cold Days is a radical work at least to the same extent), this is why in the following I will deal with the detailed analysis of Fábri's film.

How does Twenty Hours create the historical and political identity of the Second World War and the contemporary present, and how does this relate to the official memory politics of the consolidating Kádár regime? As concerns the interpretation of Twenty Hours from the perspective of consolidation politics, it is worth evoking Sándor Radnóti's appreciation of the novelist, which mentions the literary-political circumstances of the interpretive discourse around the novel's release.

The power that defeated the 1956 revolution, and especially the consolidation, were in desperate need of a valuable work of art, rather than a propaganda work, which justified the happenings in an authentic way; after several attempts Sánta's Twenty Hours seemed suitable for this demand. This is why celebrating reviews were published, in an unusual way, already after its publication in a journal, and in the following year Zoltán Fábri had the possibility of directing a film based on the novel. The followers of consolidation, and also those few who defined themselves through their loyalty to the revolution, admitted that Elnök Jóska’s figure is a Kádár apology - in a complex manner and with an artistic force. (2010a, 48-49)

Based on the schematic presentation of the novel's history, the author does not call into question the possibility of this ideological interpretation. According to him, "[moralization] does not get dissolved in the novel's deeper layers; the truths of the two protagonists emerge from among the gallery of the richly concretized secondary characters with an equal power and in an undefinable way" (Radnóti 2010a, 49). As a consequence, "Sánta's true imagination as a novelist endowed each character with their own truths" (Radnóti 2010a, 50; emphasis in the original). 
In another study, surveying the films on 1956, Radnóti nuances the interpretation of Fábri's adaptation from the point of view of consolidation, commonly known and not the least unfounded, in a similar way:

Ingenuously compressing Ferenc Sánta's novel, the script written by Yvette Bíró and Miklós Köllő related a story in which almost everybody had their relative truths. [...] This large-scale dramaturgy of relative truths makes possible that the truth of Elnök Jóska's career, obviously destined to be more or less absolute, also becomes relativized, which leads to what used to be called (in the wake of Friedrich Engels) the triumph of realism. (2010b, 305-306)

Besides the role of the "large-scale dramaturgy of relative truths," it is worth mentioning the "large-scale modernism" of the dissolution of chronology and simultaneous viewpoints in order to emphasize the relevance of Fábri's adaptation from the perspective of the history of form, through which it even surpasses the novel's poetical solutions. To all this, Fábri's monographer adds the following comment: "[As] compared to the novel, the film's temporal and spatial structure became even more modern: the spectator had to activate greater energies in order to reconstruct the story" (Marx 2004, 140).

Due to the medium specific features, namely montage and the realism of the filmic image, in Twenty Hours the dissolution of chronology and the multiplication of viewpoints confront the receiver, even more powerfully than the conceptual way of expression, with the relative nature of reality/truth. The alternation of time planes through quick montage makes the chronological and causal arrangement of events impossible and leaves open several alternative solutions before the right order and causality in the flow of the story is slowly arranged in the spectator's consciousness. The repetition of certain plot elements has a similar consequence, especially if they are repeated from a somewhat altered viewpoint. It is not the event itself that is thus questioned; through the juxtaposition of several alternative presentations it is the viewpoint/interpretation of the event that is relativized. This draws attention to the various interpretive possibilities of reality and truth, through the coequal and effective representation of diverse verisimilitudes, made possible by the realism of the filmic image.

For instance, the quick montage of the opening sequences introduces all the time planes and characters of the story; however, the lack of narrative connection among the time planes and characters makes impossible (for the time being) their placement within the story. The repeated representation of the gun scene, constituting the dramaturgical peak, from several points of view, has a similar effect. Several other recurrent form solutions contribute to making the spatialtemporal boundaries, their order as well as the viewpoint ambiguous; such is the jump cut, or as its opposite, the insert of the same spatial element from the 
same point of view, on different time planes; the asynchrony of image and sound representing distinct time planes; the freeze frame of flashbacks expressing the heightened state of mind of the one who remembers.

Fábri's procedure of dissolving chronology simultaneously formulates, through juxtaposition and as a flow, the historical and political identity of the sixties, the expression of which is carried out by resorting to the modernist non-chronological mode of narration. At the same time, in the light of the era's politics, the interpretation of historical and political identity shows a different image. As concerns historical identity, the deep disillusionment, following the joy of the 1945 redistribution of land, in the dogmatic politics of the fifties, which leads to the 1956 revolution, is subversively revealed. But as concerns political identity, from among the juxtaposed and thus subversively relativized truths of the characters of different backgrounds and mentalities, there emerges one single truth, the one which can be identified with the statement of the Kádárian consolidation. This emphasis is carried out not through the non-chronological mode of narration, but simply with the help of the character, Elnök Jóska's figure. Thus, the film's subversive meaning in a political sense clearly arises from the non-chronological mode of narration - or vice versa: the non-chronological mode of narration formulates a subversive political meaning, similarly to films relying on a similar form principle.

\section{6.}

In conclusion, I briefly refer to the survival of the non-chronological form in the period after the regime change. The first films of this kind, born in the period of the regime change, still continue the tradition of the "oppositional" character of the non-chronological films and evoke in this manner the events of the 1956 revolution and the ensuing retaliations, which were considered as taboos before (János Zsombolyai: On Death Row [A halálraítélt, 1989], Károly Makk: Hungarian Requiem [Magyar rekviem, 1990], András Sólyom: Hungarian Fragment [Pannon töredék, 1997]). From the turn of millennium on, these films get detached from the earlier political taboos and start speaking repeatedly about communicative and collective memory as well as historical and political identity with the help of the non-chronological form (Szabolcs Hajdu: White Palms [Fehér tenyér, 2005], Szabolcs Hajdu: Bibliothéque Pascal [Bibliothéque Pascal, 2010], Ibolya Fekete: My Mum and Other Nuts from the Family [Anyám és más futóbolondok a családból, 2015]). The fact that in spite of the fundamentally changed social, political, ideological, economic and institutional conditions, this form has survived and is still present in the Hungarian film art proves the significance of this form historical tradition - and it tells a lot about the forms of recall and memory politics of contemporary Hungarian film as well. This may constitute the subject matter of another paper. 


\section{Works Cited}

Assmann, Jan. 1992. Das kulturelle Gedächtnis: Schrift, Erinnerung und politische Identität in frühen Hochkulturen. [Cultural Memory and Early Civilization: Writing, Remembrance and Political Imagination.] München: Verlag C. H. Beck.

Foucault, Michel. 1971. L'ordre du discours. [The Order of Discourse.] Paris: Gallimard.

György, Péter. 2010. “Az amnéziaterápia: A Kádár-korszak fausti egyezsége.” ["Amnesia Therapy. The Faustian Pact of the Kádár Regime."] In Apám helyett [Instead of My Father], 17-69. Budapest: Magvető.

Kovács, András Bálint. 2002. "A történelmi horror: Az erőszak ábrázolása a nyolcvanas évek magyar filmjeiben." ["The Horror of History: Representation of Violence in the Hungarian Films of the Eighties."] In $A$ film szerint a világ [The World According to Film], 283-298. Budapest: Palatinus.

Kovács, András Bálint. 2005. A modern film irányzatai: Az európai múvészfilm 1950-1980. [Trends of Modern Film: European Art Film 1950-1980.] Budapest: Palatinus.

Marx, József. 2004. Fábri Zoltán: Fák és folyondárok, egy komoly filmrendezó pályaképe. [Zoltán Fábri: Trees and Ivies, the Career of a Serious Filmmaker.] Budapest: Vince.

Murai, András. 2008. Film és kollektív emlékezet: Magyar múltfilmek a rendszerváltozás után. [Film and Collective Memory: Post-Communist Hungarian Films of the Past.] Szombathely: Savaria University Press.

Radnóti, Sándor. 2010a. “Sánta Ferenc (1927-2008).” In Az Egy és a Sok: Bírálatok és méltatások. [The One and the Many: Criticism and Appreciation], 48-52. Pécs: Jelenkor.

Radnóti, Sándor. 2010b. "Határesetek. '56-os filmek. Élménybeszámoló.” ["Border Cases. Films on 1956. An Account of Experiences."] In Az Egy és a Sok: Bírálatok és méltatások. [The One and the Many: Criticism and Appreciation], 303-313. Pécs: Jelenkor.

Vasy, Géza. 1975. Sánta Ferenc. Budapest: Akadémiai.

Zappe, László. 1975. Cseres Tibor. Budapest: Akadémiai.

\section{Filmography}

Fábri, Zoltán: The Unfinished Sentence (141 perc a Befejezetlen mondatból, 1974)

Fábri, Zoltán: The Fifth Seal (Az ötödik pecsét, 1976)

Fábri, Zoltán: Twenty Hours (Húsz óra, 1965)

Fábri, Zoltán: Darkness in Daytime (Nappali sötétség, 1963)

Fábri, Zoltán: Requiem (Requiem, 1981) 
Fábri, Zoltán: Late Season (Utószezon, 1966)

Fehér, Imre: Truth Cannot Be Hidden (Húsz évre egymástól, 1962)

Fekete, Ibolya: My Mum and Other Nuts from the Family (Anyám és más futóbolondok a családból, 2015)

Gaál, István: Baptism (Keresztelő, 1967)

Gertler, Viktor: The Last Circle (Az utolsó kör, 1968)

Grunwalsky, Ferenc: Requiem for a Revolutionary (Vörös rekviem, 1975)

Gyöngyössy, Imre: Expectations (Várakozók, 1975)

Hajdu, Szabolcs: Bibliothéque Pascal (Bibliothéque Pascal, 2010)

Hajdu, Szabolcs: White Palms (Fehér tenyér, 2005)

Herskó, János: Dialogue (Párbeszéd, 1963)

Huszárik, Zoltán: Sindbad (Szindbád, 1971)

Keleti, Márton: Evidence (Ha egyszer húsz év múlva, 1964)

Kovács, András: Cold Days (Hideg napok, 1966)

Kurosawa, Akira: Rashomon (1950)

Magyar, József: Thorny Past (Korkedvezmény, 1979)

Makk Károly: Cats Play (Macskajáték, 1974)

Makk, Károly: Hungarian Requiem (Magyar rekviem, 1990)

Makk, Károly: Love (Szerelem, 1970)

Mamcserov, Frigyes: The Doctor's Death (Az orvos halála, 1965)

Mészáros, Márta: Diary for My Children (Napló gyermekeimnek, 1982)

Novák, Márk: The Martyrdom of St. John (Szentjános fejevétele, 1965)

Resnais, Alain: Last Year at Marienbad (L'année dernière à Marienbad, 1961)

Révész, György: At Midnight (Éjfélkor, 1957)

Révész, György: Who Has Ever Seen Me? (Ki látott engem?, 1977)

Révész, György: A Journey Around My Skull (Utazás a koponyám körül, 1970)

Révész, György: There Was Once a Family (Volt egyszer egy család, 1972)

Rózsa, János: Dreaming Youth (Álmodó ifjúság, 1974)

Sólyom, András: Hungarian Fragment (Pannon töredék, 1997)

Szabó, István: Father (Apa, 1966)

Szabó, István: Love Film (Szerelmesfilm, 1970)

Szabó, István: 25, Fireman's Street (Tüzoltó utca 25., 1973)

Szász, Péter: The Great Love of Your Life and How to Forget It (Hogyan felejtsük el életünk legnagyobb szerelmét?, 1979)

Szörény, Rezső: Reflections (Tükörképek, 1976)

Várkonyi, Zoltán: Face to Face (Szemtől szembe, 1970)

Welles, Orson: Citizen Kane (1941)

Zolnay, Pál: The Sack (...hogy szaladnak a fák!, 1966)

Zolnay, Pál: You Were a Prophet, My Dear (Próféta voltál szívem, 1968)

Zolnay, Pál: Shaman (Sámán, 1977)

Zsombolyai, János: On Death Row (A halálraítélt, 1989) 